\title{
Erratum to: Winter storm- and summer thunderstorm-related loss events with regard to climate change in Germany
}

\author{
Friedrich-Wilhelm Gerstengarbe • Peter C. Werner • \\ Hermann Österle • Tobias Pardowitz • Olaf Burghoff
}

Published online: 26 March 2013

(C) European Union 2013

\section{Erratum to: Theor Appl Climatol}

\section{DOI 10.1007/s00704-013-0843-y}

Unfortunately, the author Tobias Pardowitz was omitted in the original version of the article. The missing author's name with affiliation and the correct order of authors are now corrected in this article.

The online version of the original article can be found at http://dx.doi.org/ 10.1007/s00704-013-0843-y.

F.-W. Gerstengarbe $(\bowtie) \cdot$ P. C. Werner $\cdot$ H. Österle

Potsdam Institute for Climate Impact Research, Telegraphenberg,

P.O. Box 6012 03, D-14412 Potsdam, Germany

e-mail: gerstengarbe@pik-potsdam.de

T. Pardowitz

Freie Universität Berlin, Institut für Meteorologie,

Carl-Heinrich-Becker-Weg 6-10,

12165 Berlin, Germany

O. Burghoff

German Insurance Association, D-10117 Berlin, Germany 